\title{
Prevalence of bacterial spot in tomato fields of Karnataka and effect of biological seed treatment on disease incidence
}

\author{
R. Kavitha, S. Umesha* \\ Department of Applied Botany, Seed Pathology and Biotechnology, University of Mysore, Manasagangotri, Mysore 570 006, Karnataka, India
}

Received 24 May 2006; received in revised form 6 September 2006; accepted 10 September 2006

\begin{abstract}
Bacterial spot disease of tomato caused by Xanthomonas vesicatoria was studied during the field survey in the Karnataka state, India. The disease incidence ranged from $22 \%$ to $50 \%$. The pathogen was isolated from the infected plant material and seed samples. In the laboratory the pathogen was isolated following the routine laboratory assay method i.e. direct plating method using Tween B medium. Further the pathogen was confirmed by biochemical, physiological, hypersensitivity in tobacco (Nicotiana tabaccum) plants and finally the pathogenicity tests. Biological seed treatment with antagonistic Pseudomonas fluorescens improved the seed quality $(p=0.05)$ under laboratory conditions and tremendously decreased the bacterial spot disease incidence in field.
\end{abstract}

(C) 2006 Elsevier Ltd. All rights reserved.

Keywords: Bacterial spot; Tomato; Xanthomonas vesicatoria; Pseudomonas fluorescens; Seed treatment

\section{Introduction}

In India, tomato (Lycopersicon esculentum Mill.) production of 7.3 million tonne, is grown on 0.72 million hectares with a productivity of $9.1 \mathrm{tha}^{-1}$ (FAO, 2005). Tomato is prone to a number of bacterial diseases, among which the bacterial spot disease caused by Xanthomonas vesicatoria (Doidge) Dye is a serious problem (Jones et al., 1998). The bacterial spot pathogen is seed-borne, and persists as epiphytic populations on asymptomatic seedlings and mature plants (Yang et al., 2005). X. vesicatoria is more prevalent in regions with high humidity and heavy rainfall. In the field, the bacterium is disseminated through aerosols, enter small wounds or stomata and produces small water-soaked lesions, which become necrotic (Morales et al., 2005). Once the disease is established in a crop, currently available management strategies are only partially effective under environmental conditions for disease development and spread (Jaber et al., 2003). Though

\footnotetext{
*Corresponding author. Tel./fax: +918212419884(O), 9449264384 (M).

E-mail addresses: su@appbot.uni-mysore.ac.in, pmumesh@yahoo.com (S. Umesha).
}

bacterial diseases are difficult to control, various measures have been suggested to manage them. Control strategies are based on combinations of practice such as the use of pathogen free seed and transplants, elimination of volunteer tomato plants, use of resistant cultivars, frequent application of a copper and mancozeb mixture (Obradovic et al., 2004) and the use of biological agents. Chemical control has been used extensively for controlling bacterial spot disease. Growers rely heavily on fixed copper sprays to manage foliar diseases and reduce losses caused by bacterial spot and bacterial speck (Kousik and Ritchie, 1996). Unfortunately, these sprays often are not very effective and their extensive use led to the development of copper resistant strains (Adaskaveg and Hine, 1985; Cuppels and Elmhirst, 1999). Recently, combination of acibenzolar-S-methyl (ASM), a plant activator and bacteriophages were found to be effective against the bacterial spot pathogen in providing better disease control (Obradovic et al., 2004).

Biological control is an ecologically sound, environmental-friendly strategy to reduce the dependence of highrisk chemicals for disease management (Anith et al., 2004). Pseudomonas fluorescens (Trevisan) Migula has been recognized as a biocontrol agent against certain seed- and 
soil-borne plant pathogens (Anuratha and Gnanamanikam, 1990). P. fluorescens is proven as an important antagonist of Xanthomonas oryzae pv. oryzae in rice (Vidhyashekaran et al., 2001), Ralstonia solanacearum in Chilli (Umesha et al., 2006) and Clavibacter michiganensis ssp. michiganensis (Umesha, 2006). Tomato plants inoculated with $P$. fluorescens had increased dry weight, fruit weight and fruit yield (Amara et al., 1996). P. fluorescens also improved seed quality under laboratory conditions and drastically reduced bacterial canker disease in field conditions (Umesha, 2006).

$X$. vesicatoria can over-winter in soil and crop residue. Seed transmission of the pathogen is of significance for the seed trade and in quarantine inspection for seed exchange. Since the bacterial spot symptoms were noticed in tomato fields grown in Mysore and surrounding areas, the present studies were taken up with the following objectives: a field survey in major tomato growing districts of Karnataka state for bacterial spot disease incidence and to determine the effect of biological seed treatment on bacterial spot disease incidence under field conditions.

\section{Materials and methods}

\subsection{Field survey for the incidence of bacterial spot disease and collection of seed samples}

The field survey was undertaken in the major tomato growing districts of Karnataka, India. Tomato plants in the fields were inspected at the nursery stage, post transplanting, at flowering and at fruiting. Spot incidence was estimated among the randomly selected subplots (10 subplots ha ${ }^{-1}$, measuring $1 \mathrm{~m}^{2}$ ). The plants were observed for typical symptoms of bacterial spot disease viz., necrotic lesions, small spots, which are generally dark brown and circular (can be angular) on the leaves, stems, and fruits spurs, fruit lesions begin as small, slightly raised blisters. As spots increase in size, they become dark brown, scab-like, and slightly raised. Developing lesions may have a faint prominent halo, which eventually disappears. The suspected plant material and fruits were collected from the field survey and brought to the laboratory for confirmation of the disease and disease causing organism.

\subsection{Screening of plant material/seed samples for the presence of $X$. vesicatoria in the laboratory}

Plant materials/seeds collected from the suspected plants during the field survey and seed samples procured from local seed agencies, were subjected to screening under laboratory conditions by a direct plating method onto Tween B medium. Collected plant material/seed samples were plated directly on to the semi-selective medium (Tween B) (McGurie et al., 1986) after surface sterilization with $70 \%$ ethyl alcohol, followed by repeated washing with distilled water and blot drying. Plates were incubated at $28 \pm 2{ }^{\circ} \mathrm{C}$ for $24-48 \mathrm{~h}$. Yellow colonies with clear hydrolytic zones around the pieces of plant material and seeds were observed, subcultured onto the Tween B media, and the suspected colonies were subjected to biochemical, physiological, hypersensitive and pathogenicity tests for confirmation of the pathogen. Colony morphology was studied on the semi-selective media where in the resulting colonies of $X$. vesicatoria have a fried egg appearance with yellow, mucoid center surrounded by a zone of lipolysis (McGurie et al., 1986). Isolated bacteria were then streaked on to nutrient agar (NA) media and 24-48 h-old-cultures were used as required. Experiments were conducted with four replicates of 100 pieces/seeds each and repeated in two consecutive seasons.

\subsection{Characterization of the pathogen}

Characterization of the pathogen was carried out by subjecting the isolated bacterial colonies to various biochemical tests like Gram's staining, $\mathrm{KOH}$ solubility test, Kovac's (1956) oxidase test (Hildebrand and Senroth, 1972), Levan formation, Gelatin hydrolysis, Starch hydrolysis, Casein hydrolysis (Vidaver and Davis, 1988), $\mathrm{H}_{2} \mathrm{~S}$ production from peptone and Arginine dihydrolase test (Lelliott and Stead, 1987). The strains were subjected to hypersensitive reaction (HR) test using tobacco (Nicotiana tabaccum) plants (Carlton et al., 1998) and pathogenicity test (Lelliott and Stead, 1987). Each test was conducted with four replicates for each strain and repeated twice.

\subsection{Mass multiplication of $X$. vesicatoria}

Isolated and characterized $X$. vesicatoria was maintained on Tween B medium in the dark at $4{ }^{\circ} \mathrm{C}$. The inoculum was prepared by growing the bacteria in nutrient broth incubated at $28 \pm 2{ }^{\circ} \mathrm{C}$ for $36 \mathrm{~h}$ on rotary shaker at $100 \mathrm{rpm}$ (Janke and Kunkel, IKA Labortechnik, Germany). The $36 \mathrm{~h}$-old-culture was pelleted by centrifugation (thrice at $5000 \mathrm{rpm}$ for $5 \mathrm{~min}$ ) using a bench-top refrigerated centrifuge (UniCen, 15 DR, Herolab GmbH, Germany). Inoculum was prepared by adjusting the optical density (OD) of the bacterial suspension to $0.45\left(\mathrm{~A}_{610} \mathrm{~nm}\right)$ to obtain approximately $1 \times 10^{8} \mathrm{cfu} \mathrm{m}^{-1}$ with the help of UV-visible spectrophotometer (Hitachi U-2000, Tokyo, Japan) (Mortensen, 1999).

\subsection{Effect of $X$. vesicatoria on seed germination and seedling vigor of tomato under laboratory conditions}

Seeds of three tomato cultivars PKM-1, Allrounder and Avinash were treated with $X$. vesicatoria pure culture at the rate $1 \times 10^{8} \mathrm{cfu} \mathrm{ml}^{-1}$. Tomato seeds were immersed in the bacterial suspension and shaken continuously for $12 \mathrm{~h}$. Seeds immersed in sterile distilled water served as controls. After $12 \mathrm{~h}$, treated and untreated seeds were air dried, plated on wet blotters and germination rates were determined according to the standard blotter method (ISTA, 2003). Vigor index was calculated using the formula 
(mean root length + mean shoot length $) \times$ percent germination (Abdul Baki and Anderson, 1973). The experiment was carried out with four replicates of 100 seeds each and repeated twice.

\subsection{Screening of tomato seed samples for bacterial spot incidence under field conditions}

Field experiments were conducted in the experimental plot of the department to evaluate the tolerance ability of the 20 tomato cultivars against seed-borne $X$. vesicatoria infection under field conditions. Four week-old-seedlings of all 20 tomato cultivars were transplanted into the field from raised beds $(1 \times 4 \mathrm{~m})$. The seedlings were planted leaving $0.5 \mathrm{~m}$ distance between plants and $1.3 \mathrm{~m}$ between rows. Experimental plots consisted of 10 replicates with 18-20 plants per replicate. A buffer zone of a single row without seedlings was maintained between replicates. Plots were irrigated through furrow irrigation. A randomized complete block design was employed for replicated rows. All the normal agronomical practices like application of fertilizer once in every 20 days, weeding as and when required etc. were maintained throughout the experiment.

Disease assessment in field plots was done by counting the number of infected plants at 10-d intervals up to the fruiting stage starting from the appearance of first symptoms. The disease was confirmed by observing the infected leaf section from the bacterial ooze under compound microscope, plating the pieces of leaflet showing symptoms onto Tween B media and subjecting the isolated bacteria to various biochemical, physiological, HR and pathogenicity tests. Experiments were conducted in three consecutive seasons and average disease incidence was calculated.

\subsection{Mass multiplication of biological agent}

The antagonistic strain of $P$. fluorescens was isolated from native soil taken from farmers' fields and serially diluted on King's B medium (KMB) (King et al., 1956). The isolated $P$. fluorescens was further confirmed by performing various tests specific to $P$. fluorescens (Stainer et al., 1966). The 48 h-old-culture from King's B broth was centrifuged at $10,000 \mathrm{rpm}$ for $10 \mathrm{~min}$ using bench top centrifuge (UniCen, 15 DR, Herolab GmbH, Germany). Inoculum was prepared by adjusting the bacterial concentration with sterile distilled water to $1 \times 10^{8} \mathrm{cfu} \mathrm{m}^{-1}$ at $\mathrm{A}_{610} \mathrm{~nm}(\mathrm{OD}=0.45)$ using $\mathrm{UV}$-visible spectrophotometer (Hitachi U-2000, Tokyo, Japan) (Mortensen, 1999). The talcum powder based formulation of $P$. fluorescens $\left(2.8 \times 10^{8} \mathrm{CFU} \mathrm{g}^{-1}\right)$ was prepared by mixing $100 \mathrm{ml}$ of bacterial suspension in $25 \mathrm{~g}$ of purified talcum powder under sterile conditions. Carboxy methyl cellulose $(2.5 \mathrm{~g})$ was added to $250 \mathrm{~g}$ of the formulation, shade dried, packed in polythene bags and used for further experiments (Umesha et al., 1998).
2.8. Effect of P. fluorescens on seed quality parameters under laboratory conditions and bacterial spot incidence under field conditions

Tomato cultivars previously screened for the presence of the bacterial spot pathogen in both laboratory and field conditions were treated with the suspension of $P$. fluorescens by shaking the seeds in a pure culture of $P$. fluorescens $\left(1 \times 10^{8} \mathrm{cfu} \mathrm{ml}^{-1}\right)$ for $12 \mathrm{~h}$. The first set of samples were soaked in distilled water which served as a control. The second set was treated with the above formulation of $P$. fluorescens in the form of a slurry treatment at the rate of $10 \mathrm{~g} \mathrm{~kg}^{-1}$ seeds. After $12 \mathrm{~h}$, the treated and untreated seeds were air dried, plated on wet blotters and germination rates were determined according to the standard blotter method (ISTA, 2003). Vigor index was calculated using the formula (mean root length + mean shoot length) $\times$ percent germination (Abdul Baki and Anderson, 1973). The experiment was carried out with four replicates of 100 seeds each and repeated twice.

Field trials were carried out using the same 20 tomato cultivars with $P$. fluorescens formulation treatment with appropriate controls. Treatment was the slurry treatment, as explained previously for the field experiments. Field plots were inoculated with $X$. vesicatoria suspension $\left(1 \times 10^{8} \mathrm{cfu} \mathrm{ml}^{-1}\right)$ during the early morning and late evening as a spray inoculation. Plants were sprayed with suspension of pathogen to run-off $48 \mathrm{~h}$ after transplantation. In all the field experiments, there were five replicates of all the cultivars in a randomized block design with 25-30 plants in each replicate. Each experiment was repeated in three consecutive seasons. Plants were closely observed from day 7 after inoculation until the fruiting stage, for typical symptoms of bacterial spot disease as explained earlier.

\subsection{Statistical procedure}

Data on percentages was transformed to arcsine square root equivalents prior to analysis of variance (ANOVA). Means were separated using Duncan's multiple range test, (DMRT; $p=0.05)$ using SPSS software.

\section{Results}

PKM-1, Allrounder and Avinash were the popularly grown tomato cultivars identified during the field survey in both seasons. Disease incidence was 29\% in Mysore and $50 \%$ in Mandya with cv. PKM-1 in both seasons. Whereas in Bangalore and Kolar it was $31 \%$ and $22 \%$ with cvs. Avinash and Allrounder, respectively, in both seasons.

\subsection{Screening of tomato cultivars and characterization of the $X$. vesicatoria}

The colonies of $X$. vesicatoria on Tween B medium appeared as fried egg like colonies with a yellow, mucoid, 
centre, surrounded by zone of lipolysis. Based on the morphological criteria, the suspected colonies were sub cultured to NA and subjected to further characterization. The results of the 20 tomato cultivars subjected to screening for the presence of seed-borne $X$. vesicatoria using direct plating method on Tween $\mathrm{B}$ medium are depicted in Table 1. Among the tomato cultivars tested using the direct plating method, none of them were free of $X$. vesicatoria. However, the disease incidence ranged from $3 \%$ to $19 \%$ across all the tomato cultivars. Only one cv., Golden recorded a 5\% incidence, the cultivars Allrounder, $P K M-1$ and Avinash recorded $17 \%, 11 \%$ and $16 \%$ $X$. vesicatoria incidence, respectively. On the other hand, bacterial spot incidence in the cv. Golden was not detected in the field experiments, whereas Allrounder, PKM-1 and Avinash recorded $10 \%, 4 \%$ and $9 \%$ bacterial spot disease incidence, respectively. The incidence of bacterial spot under field conditions ranged from $4 \%$ to $12 \%$. The tomato cultivars namely Allrounder (10\%), Sungro (10\%), Madanapalli (10\%) and Arka abha (12\%) recorded more than $10 \%$ disease incidence under field conditions (Table 1).

Table 1

Screening of tomato cultivars for the presence of $X$. vesicatoria under laboratory conditions and bacterial spot disease incidence under field conditions

\begin{tabular}{lll}
\hline Tomato cultivars & $\begin{array}{l}\text { Incidence of } X . \\
\text { vesicatoria }(\%)^{\mathrm{a}}\end{array}$ & $\begin{array}{l}\text { Incidence of bacterial } \\
\text { spot disease }(\%)^{\mathrm{b}}\end{array}$ \\
\hline Allrounder & $17 \pm 0.6$ & $10 \pm 0.5$ \\
PKM 1 & $11 \pm 0.5$ & $4 \pm 0.2$ \\
Avinash & $16 \pm 0.6$ & $9 \pm 0.5$ \\
Lakshmi & $12 \pm 0.5$ & $5 \pm 0.6$ \\
Leadbeter & $13 \pm 0.5$ & $5 \pm 0.6$ \\
Vijaya & $17 \pm 0.6$ & $9 \pm 0.8$ \\
Quality & $16 \pm 0.6$ & $9 \pm 0.8$ \\
Sungro & $18 \pm 0.7$ & $10 \pm 0.9$ \\
Golden & $3 \pm 0.2$ & 0 \\
Valley & $12 \pm 0.5$ & $4 \pm 0.5$ \\
Solar & $13 \pm 0.5$ & $5 \pm 0.6$ \\
Safal & $15 \pm 0.6$ & $8 \pm 0.8$ \\
Solar round & $15 \pm 0.6$ & $8 \pm 0.8$ \\
Ashoka & $14 \pm 0.5$ & $5 \pm 0.6$ \\
Madanapalli & $18 \pm 0.6$ & $10 \pm 0.9$ \\
Sasya & $12 \pm 0.5$ & $4 \pm 0.6$ \\
Naveen & $14 \pm 0.6$ & $5 \pm 0.6$ \\
Arka aloka & $15 \pm 0.6$ & $6 \pm 0.8$ \\
Arka megana & $13 \pm 0.5$ & $5 \pm 0.6$ \\
Arka abha & $19 \pm 0.9$ & $12 \pm 0.9$ \\
\hline
\end{tabular}

${ }^{\mathrm{a}}$ Results of direct plating method, tomato seeds were surface sterilized and plated on Tween B media and incubated at $28+2{ }^{\circ} \mathrm{C}$ for $48 \mathrm{~h}$. Seeds showing the bacterial colonies with fried egg appearance were screened. Values are the means \pm SE of four replicates of 100 seeds each and repeated twice.

${ }^{\mathrm{b}}$ Results of field screening, tomato seeds were sown in the experimental plot and transplanted after 4 weeks from the nursery beds. Bacterial spot incidence was screened after 10 days of transplantation and up to fruiting stage. Values are the replicates means \pm SE of 10 replicates of $18-20$ plants each and repeated thrice.
Table 2

Biochemical characterization tests of the pathogen $X$. vesicatoria

\begin{tabular}{ll}
\hline Tests & Results \\
\hline Gram's Staining & - \\
KOH solubility & + \\
Arginine dihydrolase & + \\
Gelatin hydrolysis & - \\
Starch hydrolysis & - \\
Levan formation & - \\
Lipase activity & + \\
Casein hydrolysis test & + \\
$\mathrm{H}_{2}$ S production test & + \\
Kovac's oxidase test & - \\
Oxidation/fermentation & + \\
Tobacco hypersensitive & + \\
reaction & \\
Pathogenicity test & + \\
\hline
\end{tabular}

All these tests were conducted in 4 replicates and were repeated thrice. ' + ' indicates positive reaction; '-' indicates negative reaction.

The bacterium on Tween B medium plates, was tentatively identified as $X$. vesicatoria. Infected stem and root portions showed discolorations when cut open. Milky white bacterial ooze was observed when plant material was placed in water. Healthy plant material did not show any discoloration or bacterial ooze. The results of physiological and biochemical tests of the bacterium are shown in Table 2. Necrosis was observed in tobacco plants, within $24 \mathrm{~h}$ of infiltration with bacterial cells, whereas sterile distilled water infiltered leaf region did not show any change in the leaf color, which served as a control. Tomato plants inoculated with the strains showed bacterial spot symptoms after $15 \mathrm{~d}$. Control plants inoculated with sterile distilled water did not show any symptoms (Table 2).

\subsection{Effect of X. vesicatoria on tomato seed germination and seedling vigor}

There was a significant change $(p=0.05)$ in the seed germination of tomato seeds with and without $X$. vesicatoria inoculation. Seed germination in cv. Allrounder was reduced from $78 \%$ in the untreated control to $38 \%$ when the seeds were treated with $X$. vesicatoria. A similar trend was reflected in the other two tomato cultivars. The mean shoot and root lengths were reduced from 2.6 to $5.7 \mathrm{~cm}$ in the untreated control to 1.7 and $2.8 \mathrm{~cm}$ when the tomato seed cv. Avinash was treated with $X$. vesicatoria. The vigor index was significantly reduced $(p=0.05)$ from 663 in the control to 175 when the seeds were exposed to $X$. vesicatoria (cv. Allrounder). The same trend was noticed with the other two tomato cultivars (Table 3).

\subsection{Effect of P. fluorescens and its formulation on tomato seed germination and seedling vigor under laboratory conditions}

There was a significant improvement $(p=0.05)$ in seed germination when tomato seeds were treated with 
Table 3

Effect of $X$. vesicatoria on tomato seed germination and seedling vigor

\begin{tabular}{lllll}
\hline Tomato cultivars & Germination (\%) & MSL (cm) & MRL (cm) & VI \\
\hline Allrounder & & & & \\
Control & $78^{\mathrm{a}}$ & $2.7^{\mathrm{a}}$ & $5.8^{\mathrm{a}}$ & $663^{\mathrm{a}}$ \\
Treated & $38^{\mathrm{b}}$ & $1.5^{\mathrm{b}}$ & $3.1^{\mathrm{b}}$ & $175^{\mathrm{b}}$ \\
PKM 1 & & & & \\
Control & $72^{\mathrm{a}}$ & $2.9^{\mathrm{a}}$ & $6.0^{\mathrm{a}}$ & $641^{\mathrm{a}}$ \\
Treated & $41^{\mathrm{b}}$ & $1.9^{\mathrm{ab}}$ & $3.2^{\mathrm{b}}$ & $209^{\mathrm{c}}$ \\
Avinash & & & & \\
Control & $67^{\mathrm{a}}$ & $2.6^{\mathrm{ab}}$ & $5.7^{\mathrm{a}}$ & $556^{\mathrm{ab}}$ \\
Treated & $32^{\mathrm{b}}$ & $1.7^{\mathrm{b}}$ & $2.8^{\mathrm{ab}}$ & $144^{\mathrm{a}}$ \\
\hline
\end{tabular}

Values are the means of two independent experiments of four replicates of 100 seeds each. $\mathrm{MRL}=$ mean root length; MSL = mean shoot length; $\mathrm{VI}=$ vigor index. The values in the column followed by the same letter(s) are not significantly different according to analysis of variance (DMRT; $p=0.05)$

P. fluorescens (Tables 4 and 5). Seed germination in the cv. Allrounder increased from $66 \%$ in the untreated control to $81 \%$ and $79 \%$, when the seeds were treated with pure culture and freshly prepared formulations of $P$. fluorescens. The mean shoot and root lengths were also increased with $P$. fluorescens treatment both in pure culture and the formulation. The vigor index was increased from 670 in the untreated control to 898 and 851 when the seeds were treated with $P$. fluorescens and formulation, respectively with the cv. PKM-1 (Tables 4 and 5). Among all the cultivars tested, $P$. fluorescens improved the seed quality parameters in both pure culture and formulations (Tables 4 and 5).

\subsection{Effect of P. fluorescens formulation on the incidence of bacterial spot under field conditions}

In all 20 tomato cultivars tested, bacterial spot disease incidence was significantly reduced $(p=0.05)$ upon $P$. fluorescens formulation treatment followed by challenge inoculation with $X$. vesicatoria (Fig. 1). In certain cultivars the bacterial spot incidence in the untreated control ranged from $60 \%$ to $70 \%$ was reduced to $20-30 \%$ (Group I, Fig. 1). This group includes the cultivars: Lakshmi, Leadbeter, Vijaya, Quality, Naveen and Arka alok. In Group II, the bacterial spot incidence in the untreated control ranged from $50 \%$ to $60 \%$, upon seed treatment with $P$. fluorescens formulation at the rate of $10 \mathrm{~g} \mathrm{~kg}^{-1}$ seeds followed by challenge inoculation with $X$. vesicatoria, the disease incidence was reduced to $12-18 \%$ (Fig. 1).

\section{Discussion}

Field surveys in the two consecutive seasons showed a high incidence of bacterial spot disease in the tomato fields of Karnataka. The disease was severe with an average
Table 4

Effect of $P$. fluorescens pure culture on tomato seed germination and seedling vigor

\begin{tabular}{lllll}
\hline $\begin{array}{l}\text { Tomato cultivars/ } \\
\text { treatment }\end{array}$ & $\begin{array}{l}\text { Germination } \\
(\%)\end{array}$ & MSL $(\mathrm{cm})$ & MRL $(\mathrm{cm})$ & VI \\
\hline $\begin{array}{l}\text { Allrounder } \\
\text { Control }\end{array}$ & $66^{\mathrm{c}}$ & $2.5^{\mathrm{a}}$ & $5.1^{\mathrm{a}}$ & $502^{\mathrm{a}}$ \\
Treated & $81^{\mathrm{b}}$ & $3.1^{\mathrm{b}}$ & $6.8^{\mathrm{a}}$ & $802^{\mathrm{b}}$ \\
PKM 1 & & & & \\
Control & $77^{\mathrm{a}}$ & $2.8^{\mathrm{a}}$ & $5.9^{\mathrm{c}}$ & $670^{\mathrm{a}}$ \\
Treated & $88^{\mathrm{b}}$ & $4.0^{\mathrm{b}}$ & $6.2^{\mathrm{c}}$ & $898^{\mathrm{c}}$ \\
Avinash & & & & \\
Control & $69^{\mathrm{a}}$ & $2.7^{\mathrm{a}}$ & $5.5^{\mathrm{c}}$ & $566^{\mathrm{ab}}$ \\
Treated & $82^{\mathrm{b}}$ & $3.7^{\mathrm{b}}$ & $6.8^{\mathrm{c}}$ & $861^{\mathrm{a}}$ \\
\hline
\end{tabular}

Values are the means of two independent experiments of four replicates of 100 seeds each. $\mathrm{MRL}=$ mean root length; $\mathrm{MSL}=$ mean shoot length; $\mathrm{VI}=$ vigor index. The values in the column followed by the same letter(s) are not significantly different according to analysis of variance (DMRT; $p=0.05)$.

Table 5

Effect of $P$. fluorescens formulation on tomato seed germination and seedling vigor

\begin{tabular}{|c|c|c|c|c|}
\hline $\begin{array}{l}\text { Tomato cultivars/ } \\
\text { treatment }\end{array}$ & $\begin{array}{l}\text { Germination } \\
(\%)\end{array}$ & MSL (cm) & MRL $(\mathrm{cm})$ & VI \\
\hline \multicolumn{5}{|l|}{ Allrounder } \\
\hline Control & $66^{\mathrm{c}}$ & $2.5^{\mathrm{a}}$ & $5.1^{\mathrm{a}}$ & $502^{\mathrm{a}}$ \\
\hline Seed treatment & $79^{\mathrm{b}}$ & $3.0^{\mathrm{b}}$ & $6.8^{\mathrm{a}}$ & $774^{\mathrm{b}}$ \\
\hline \multicolumn{5}{|l|}{$P K M 1$} \\
\hline Control & $77^{\mathrm{a}}$ & $2.8^{\mathrm{a}}$ & $5.9^{\mathrm{c}}$ & $670^{\mathrm{a}}$ \\
\hline Seed treatment & $86^{\mathrm{b}}$ & $4.0^{\mathrm{b}}$ & $5.9^{\mathrm{c}}$ & $851^{\mathrm{c}}$ \\
\hline \multicolumn{5}{|l|}{ Avinash } \\
\hline Control & $69^{\mathrm{a}}$ & $2.7^{\mathrm{a}}$ & $5.5^{\mathrm{c}}$ & $566^{\mathrm{ab}}$ \\
\hline Seed treatment & $80^{\mathrm{b}}$ & $3.4^{\mathrm{b}}$ & $5.8^{\mathrm{c}}$ & $736^{\mathrm{a}}$ \\
\hline
\end{tabular}

Values are the means of two independent experiments of four replicates of 100 seeds each. $\mathrm{MRL}=$ mean root length; $\mathrm{MSL}=$ mean shoot length; $\mathrm{VI}=$ vigor index. The values in the column followed by the same letter(s) are not significantly different according to analysis of variance (DMRT; $p=0.05)$.

incidence of 29\% in Mysore region, 50\% in Mandya region in cv. PKM-1, 31\% at Bangalore region and $22 \%$ at Kolar region with Avinash and Allrounder tomato cultivars. The morphological characteristics on Tween B medium, physiological, biochemical characterization results, hypersensitive response in tobacco plant leaves and pathogenicity test results confirmed that the pathogen indeed was X. vesicatoria (Bradbury, 1986; McGurie et al., 1986). The present investigation showed that for detection of $X$. vesicatoria in or on the seeds, the direct plating method can be routinely used. For detection or isolation and purification of $X$. vesicatoria Tween B medium proved to be more suitable than any other media, with great 


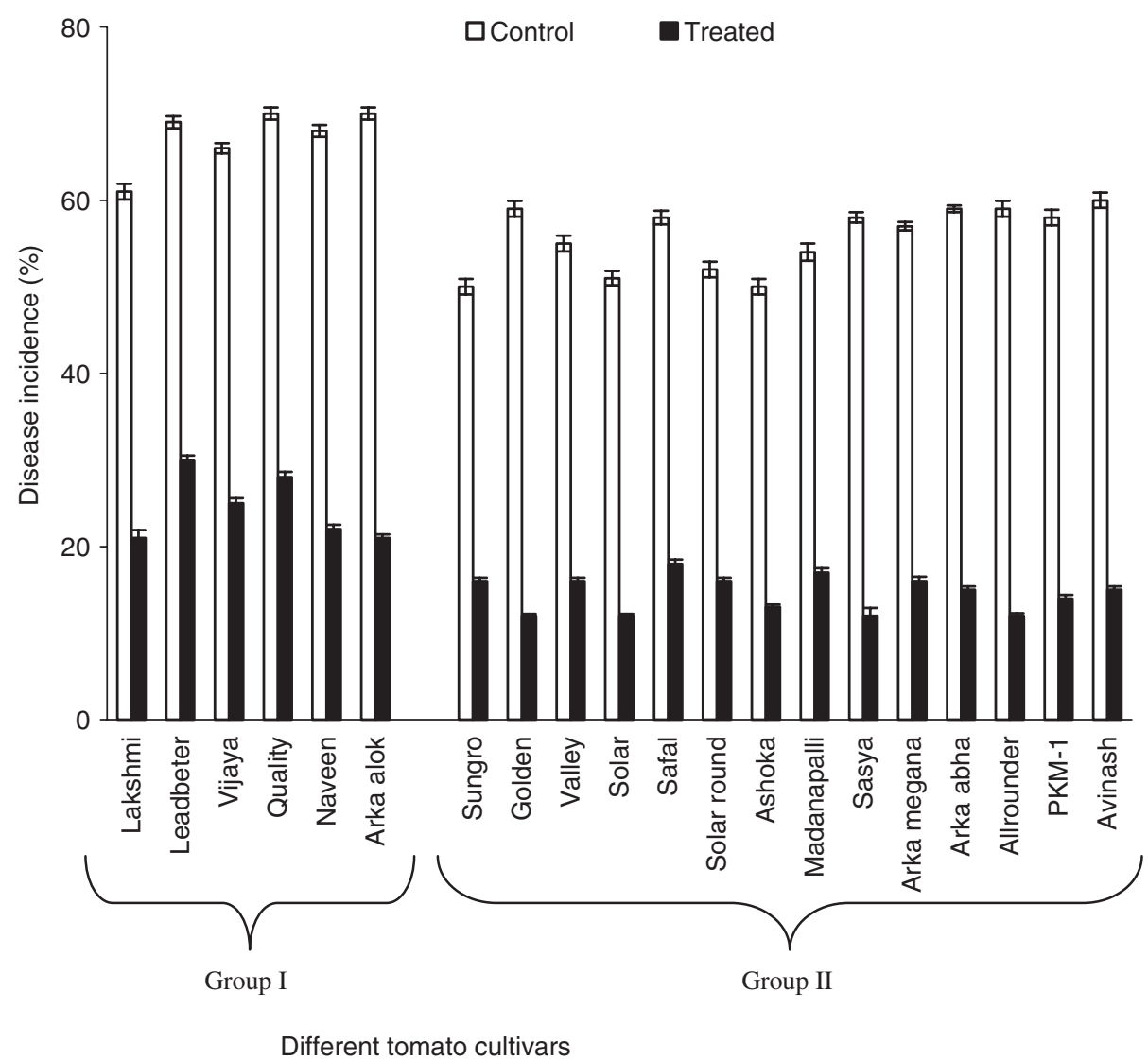

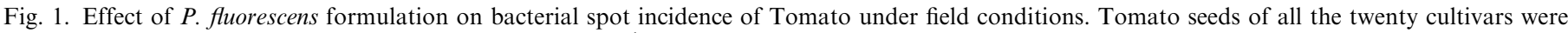

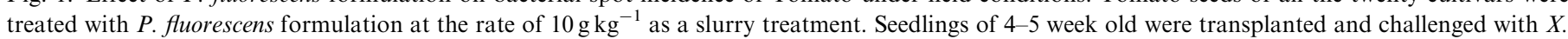

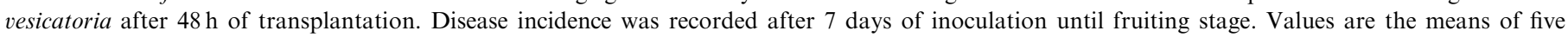
replicates of all the cultivars. The lines on each bar represents SE when subjected to analysis of variance $(\mathrm{DMRT} ; p=0.05)$.

reduction in number of saprophytes, confirming the conclusions of McGurie et al. (1986). The presence of $X$. vesicatoria on or in the seed may provide a potentially dangerous source of inoculum. In the present studies, seeds from naturally infected plants under field conditions clearly transmitted $X$. vesicatoria to seedlings, since typical symptoms of the bacterial spot disease were recorded in the field screening. However, we found that $X$. vesicatoria adversely affected tomato seed quality, as reported by Silva et al. (2004) and Ji et al. (2006).

The results obtained during the field screening of the 20 tomato cultivars for the presence of $X$. vesicatoria varied from $4 \%$ to $12 \%$; similar findings were reported by Hammond and Jones (1996). In susceptible plants, $X$. vesicatoria strains are able to multiply and spread throughout the plant, leading to the appearance of typical disease symptoms. In resistant plants, the activation of a rapid and localized cell death at the site of infection, known as hypersensitive responses (HR) limits the pathogen growth and minimizes disease symptoms. Similarly the field screening of the 20 cultivars revealed that they are grouped into two (Fig. 1), based on the degree of disease incidence shown by the cultivars.

The biocontrol agent, $P$. fluorescens may be effectively incorporated into an integrated disease management program to manage bacterial spot disease of tomato. Various control strategies, including host-plant resistance, cropping systems (Dalal et al., 1999), transgenics, resistant cultivars, soil amendments, integrated control and biological control have been developed (Guo et al., 2004). Reports from elsewhere indicate that $P$. fluorescens can effectively induce systemic resistance against fungal (Chen et al., 1995), bacterial (Alstrom, 1991; Vidhyashekaran et al., 2001) and viral (Maurhofer et al., 1994) pathogens. Potential biological agents used to control bacterial spot of tomato include selected rhizobacterial strains (Silva et al., 2004; El-Hendawy et al., 2005). Ji et al. (2006) reported that, when foliar biocontrol agents and plant growth promoting rhizobacteria were used individually or in combinations, they reduced the bacterial spot disease incidence and some naturally occurring antagonistic rhizobacteria (Guo et al., 2004). Research is going on to unravel the complex process of biological control of bacterial spot disease of tomato.

\section{Acknowledgment}

The present work is the result of a major research project entitled, "Investigations on bacterial Spot of Tomato and its management" awarded by University 
Grants Commission, Government of India, New Delhi, India, under 10th plan No. F.30-146/2004 (SR), dated 10th November 2004. The authors wish to thank the Chairman, Department of Applied Botany, Seed Pathology and Biotechnology, University of Mysore, Manasagangotri, Mysore 570 006, India.

\section{References}

Abdul Baki, A.A., Anderson, J.D., 1973. Vigour determination in soybean seed by multiple criteria. Crop Sci. 13, 630-633.

Adaskaveg, J.E., Hine, R.B., 1985. Copper tolerance and zinc sensitivity of Mexican strains of Xanthomonas campestris pv. vesicatoria, causal agent of bacterial spot of pepper. Plant Dis. 69, 993-996.

Alstrom, S., 1991. Induction of disease resistance in common bean susceptible to halo blight bacterial pathogen after seed bacterization with rhizosphere pseudomonads. J. Appl. Microbial 37, 495-501.

Anith, K.N., Momol, M.T., Kloepper, J.W., Marios, J., Olson, S.M., Jones, J.B., 2004. Efficacy of plant growth-promoting rhizobacteria, acibenzolar-S-methyl and soil amendment for integrated management of bacterial wilt on tomato. Plant Dis. 88, 669-673.

Anuratha, C.S., Gnanamanikam, S.S., 1990. Biological control of bacterial wilt caused by Ralstonia solanacearum in India with antagonistic bacteria. Plant and Soil 124, 109-116.

Amara, M.A., Rable, K.A.E., Talkran, F.N., 1996. Activity of Pseudomonas fluorescens mutants in relation to growth regulators production and biological control in tomato plants. Ann. Agric. Sci. 41, 111-124.

Bradbury, J.F., 1986. Guide to Plant Pathogenic Bacteria. CAB International, Wallingford, UK.

Carlton, W.M., Braun, E.J., Gleason, M.L., 1998. Ingress of Clavibacter michiganensis ssp. michiganensis in tomato leaves through hydathodes. Phytopathology 88, 525-529.

Chen, C., Bauske, E.M., Musson, G., Rodriguez-Kabana, R., Kloepper, J.W., 1995. Biological control of Fusarium wilt on cotton by the use of endophytic bacteria. Biol. Control 5, 83-91.

Cuppels, D.A., Elmhirst, J., 1999. Disease development and changes in the natural Pseudomonas syringae pv. tomato populations on field tomato plants. Plant Dis. 83, 759-764.

Dalal, N.R., Dalal, S.R., Golliwar, V.G., Khobrzgade, R.I., 1999. Studies on grading and pure packing of some bacterial wilt resistant Brinjal (Solanum melongena L.) varieties. J. Soil Crops 9, 223-226.

El-Hendawy, H.H., Osman, M.E., Sorour, N.M., 2005. Biological control of bacterial spot of tomato caused by Xanthomonas campestris pv. vesicatoria by Rahnella aquatilis. Microbiol. Res. 160, 343-352.

Guo, J.H., Qi, H.Y., Guo, Y.H., Ge, H.L., Gong, L.Y., Zhang, L.X., Ping, H.S., 2004. Biocontrol of Tomato wilt by plant growthpromoting rhizobacteria. Biol. Control 29, 66-72.

Food and Agriculture Organization of United Nations, Agriculture data (FAO), $2005\langle$ http://www.Faostat.com $\rangle$.

Hildebrand, D.C., Senroth, M.N., 1972. Identification of fluorescent Pseudomonads. In: In The Proceedings of the Third International Conference on Plant Pathogenic Bacteria. Center for Agricultural Publishing and Documentation, Wageningen, pp. 281-287.

Hammond, K., Jones, J.D., 1996. Resistance gene-dependent plant defence responses. Plant Cell 8, 1773-1791.

ISTA, 2003. International Rules for Seed Testing. In: Daper, S.R. (Ed.), Rules 2003. International Seed Testing Association, Zurich, Switzerland, pp. $1-520$.

Jaber, A.H., Abbasi, P.A., Miller, S.A., Hoitink, H.A.J., 2003. Suppression of bacterial spot of tomato with foliar sprays of compost extracts under green house and field conditions. Plant Dis. 87, 913-919.

Ji, P., Campbell, H.L., Kloepper, J.W., Jones, J.B., Suslow, T.V., Wilson, M., 2006. Integrated biological control of bacterial speck and spot of tomato under field conditions using foliar biological control agents and plant growth promoting rhizobacteria. Biol. Control 36, 358-367.

Jones, J.B., Bouzar, H., Somodi, G.C., Stall, R.E., Pernezny, K., ElMorsy, G., Scott, J.W., 1998. Evidence for the preemptive nature4 of tomato race 3 of Xanthomonas campestris pv. vesicatoria in Florida. Phytopathology 88, 33-38.

King, E.O., Ward, M.K., Raney, D.E., 1956. Two simple media for the demonstration of pycoyanin and fluorescein. J. Laboratory Clin. Med. 4, 301-307.

Kousik, R.S., Ritchie, D.F., 1996. Mixed varieties combined with copper sprays to manage bacterial spot of bell peppers. Phytopathology 86, 502-508.

Kovac's, N., 1956. Identification of Pseudomonas pyocyanea by the oxidase reaction. Nature, London 178, 703.

Lelliott, R.A., Stead, D.E., 1987. Methods for the diagnosis of bacterial diseases of plants. In: Preece, T.F. (Ed.), Methods in Plant Pathology, vol. II. Blackwell Scientific Publications, Oxford, p. 216.

Maurhofer, M., Hase, C., Meuwly, P., Metraux, J.P., Defago, G., 1994. Induction of systemic resistance of tobacco to tobacco necrosis virus by root colonizing Pseudomonas fluorescens strain CHAO: influence of the gac A gene and pyoverdine production. Phytopathology 84, 139-146.

McGurie, R.G., Jones, J.B., Sasser, M., 1986. Tween media for semiselective isolation of Xanthomonas campestris pv. vesicatoria from soil and plant material. Plant Dis. 70, 887-891.

Morales, C.Q., Posada, J., Macneale, E., Franklin, D., Rivas, I., Bravo, M., Minsavage, J., Stall, R.E., Whalen, M.C., 2005. Functional analysis of the early chlorosis factor gene. Mol. Plant-Microb Interact. $18,477-486$.

Mortensen, C.N., 1999. Seed-borne Bacterial Diseases. Danish Government Institute of Seed Pathology for Developing Countries. Hellerup, Copenhagen, Denmark, pp. 86-92.

Stainer, R.Y., Palleroni, N.J., Dondorff, M., 1966. The aerobic Pseudomonads: a taxonomic study. J. Gen. Microbiol. 43, 156-271.

Silva, H.S.A., Romerio, R.D.S., Macagnan, D., Halfeld-Vieira, B.D.A., Pereira, M.C.B., Mounteer, A., 2004. Rhizobacterial induction of systemic resistance in tomato plants: non-specific protection and increase in enzyme activities. Bio. Control 29, 288-295.

Obradovic, A., Jones, J.B., Momol, M.T., Balgoh, B., Olson, S.M., 2004. Management of tomato bacterial spot in the field by foliar applications of bacteriophages and SAR inducers. Plant Dis. 88, 736-740.

Umesha, S., Shylaja, M.D., Sudheer, A.S., Krishnappa, M., Shetty, H.S., 1998. Biocontrol of downy mildew disease of pearl millet using Pseudomonas fluorescens. Crop Prot. 17, 387-392.

Umesha, S., Kavitha, R., Shetty, H.S., 2006. Transmission of seed-borne infection of chilli by Burkholderia solanacearum and effect of biological seed treatment on disease incidence. Arch. Phytopathol. Plant Prot. 38, 281-293.

Umesha, S., 2006. Occurrence of bacterial canker in tomato fields of Karnataka and effect of biological seed treatment on disease incidence. Crop Prot. 25, 375-381

Vidaver, A.K., Davis, M.J., 1988. Coryneform plant pathogens. In: Schaad, N.W. (Ed.), Laboratory guide for identification of plant pathogenic bacteria, second ed. The American Phytopathological Society, St. Paul, MN, pp. 104-113.

Vidhyashekaran, P., Kamala, N., Ramanathan, A., Rajappan, K., Paranidharan, V., Velazhahan, R., 2001. Induction of systemic resistance by Pseudomonas fluorescens $\mathrm{pfl}$ against Xanthomonas oryzae pv. oryzae in rice leaves. Phytoparasitica 29, 155-166.

Yang, W., Sacks, E.J., Lewis Ivey, M.L., Miller, S.A., Francis, D.M., 2005. Resistance in Lycopersicon esculentum intraspecific crosses to race T1 strains of Xanthomonas campestris pv. vesicatoria causing bacterial spot of tomato. Phytopathology 95, 519-527. 